\title{
STRUCTURE/PROPERTY INTERACTIONS IN A LONG RANGE ORDER STRENGTHENED SUPERALLOY
}

\author{
M. F. Rothman ${ }^{1}$, D. L. Klarstrom ${ }^{1}$, M. Dollar ${ }^{2}$, and J. F. Radavich ${ }^{3}$ \\ ${ }^{1}$ Haynes International, Inc., P. O. Box 9013, Kokomo, IN 46904-9013 \\ ${ }^{2}$ Illinois Institute of Technology, 10 W. 32nd St., EL243, Chicago, IL 60616-3793 \\ ${ }^{3}$ Micro-Met Laboratories, 209 North St., West Lafayette, IN 47906
}

\begin{abstract}
An investigation of the long range ordering and secondary phase reactions in HAYNES $242^{\mathrm{TM}}$ alloy, and their relationships to the mechanical properties of this age-hardenable material, has been conducted. The structure and property responses of the material to various intermediate temperature heat treatments interposed between a solution treatment and final aging treatment have been evaluated for a range of commercial heat chemistries utilizing elevated temperature tensile testing, as well as metallographic, TEM, SEM and extraction/x-ray diffraction techniques. Results of this work indicate that these interposed intermediate temperature heat treatments have major effects upon nature of the ordered domains formed in the material during final aging, the nature and morphology of secondary phases found, and the final mechanical properties exhibited by the alloy. Results also indicate that small variations in heat chemistry can exert a measureable influence upon both structure and properties.
\end{abstract}

\section{Introduction}

Utilization of long range order as a primary mechanism for providing enhanced elevated temperature strength in commercial wrought nickel-chromium-molybdenum alloys is a relatively recent development ". The development of long range ordered domains in these alloys after long exposure at intermediate temperatures, with an attendant increase in elevated tcmpcrature strength, has been a well known phenomenon for some time ${ }^{2}$. It is only in the last 10 years, however, that compositions in the nickel-chromium-molybdenum system have been identified which allow the strengthening associated with the formation of these long range ordered domains to be achieved with a commercially viable aging time.

HAYNES 242 alloy is one such material. Containing nominally $25 \%$ molybdenum and $8 \%$ chromium by weight, with nickel as a base, this alloy exhibits up to a doubling of its yield strength over the annealed condition with aging at $650^{\circ} \mathrm{C}\left(1200^{\circ} \mathrm{F}\right)$ for from 24 to 72 hours. This strengthening is accompanied by a modest reduction in ductility, as might be expected. The increase in strength is attributable to the observed rapid formation of very small long range ordered domains with an $\mathrm{Ni}_{2}(\mathrm{Mo}, \mathrm{Cr})$ stoichiometry, very similar to those which have previously been observed to form in nominally $\mathrm{Ni}-16 \% \mathrm{Cr}-16 \% \mathrm{Mo}$ type alloys following hundreds of hours of aging ${ }^{2}$. The domains exhibit a lenticular shape, similar to that of $\gamma^{\prime \prime}$ particles in 718 alloy,

HAYNES is a registered trademark, and 242 is a trademark, of Haynes International, Inc. with a typical initial long axis dimension of about $10-20 \mathrm{~nm}$. Previous work ${ }^{3}$ has shown that these ordered domains tend to coarsen slowly with long-term exposure at temperatures above about $540^{\circ} \mathrm{C}\left(1000^{\circ} \mathrm{F}\right)$, with the coarsening rate increasing as exposure temperature increases. Long range order (and related strengthening) appears to be lost above about $760^{\circ} \mathrm{C}\left(1400^{\circ} \mathrm{F}\right){ }^{4}$, although domains have been observed to persist at or near these higher temperatures for a short exposure time ${ }^{3}$.

Since its commercial introduction in the early 1990 's, 242 alloy has been selected for a variety of gas turbine engine component applications, many of which are made from forged or rolled rings. From the onset of production-scale reforge billet and ring manufacturing, the alloy's properties have exhibited marked sensitivity to a seemingly small degree of normal compositional and thermomechanical processing variability. This has been particularly the case for elevated temperature tensile properties, for which extremes of high strength/ low ductility and high ductility/ low strength have been observed.

In the present work, efforts have been made to comprehensively and painstakingly characterize the nature of the long range ordering and secondary phase reactions in the alloy in an attempt to provide the fundamental understanding needed to remediate this problem. Our purpose was to examine the influence of minor composition variation upon those reactions, as well as the effect of short duration thermal exposure at temperatures at or above $760^{\circ} \mathrm{C}\left(1400^{\circ} \mathrm{F}\right)$, and tie the structural observations back directly to the observed tensile property effects.

\section{Materials and Experimental Details}

For these studies, reforge billets from 242 alloy commercial heats were selected with major element compositions (molybdenum and chromium) representing the high ("rich") and low ("lean") sides of the normal variation in production. Chemical analyses for study heats are given in Table 1. It should be noted that although the differences in molybdenum and chromium content among these heats might be considered minor in the context of other alloys, it was anticipated that this magnitude of variation in 242 alloy could have a significant effect upon the ordering reaction. Most of the work being presented in this paper was performed for Heat $A$ and Heat D. Only selected illustrative structures from Heat B and Heat $\mathrm{C}$ are included.

Full cross section, 51-mm (2-inch) thick samples were taken from each billet. These were hot rolled in the laboratory in the billet transverse direction, in several sessions between $1120^{\circ} \mathrm{C}$ and $1205^{\circ} \mathrm{C}\left(2050^{\circ} \mathrm{F}\right.$ and $\left.2200^{\circ} \mathrm{F}\right)$, to yield $9.5-\mathrm{mm}(0.375$-inch) thick 
TABLE I Chemical Composition of Study Heats

(Weight \%)

\begin{tabular}{|c|c|c|c|c|c|c|c|c|c|c|}
\hline Heat & $\mathrm{Ni}$ & $\mathrm{Mo}$ & $\mathrm{Cr}$ & $\mathrm{Fe}$ & $\mathrm{Mn}$ & $\mathrm{Al}$ & $\mathrm{W}$ & $\mathrm{Si}$ & $\mathrm{C}$ & $\mathrm{B}$ \\
\hline $\mathrm{A}$ & Bal. & 24.84 & 8.07 & 1.05 & 0.32 & 0.28 & 0.12 & 0.07 & 0.003 & 0.003 \\
\hline B & Bal. & 24.73 & 8.27 & 1.08 & 0.36 & 0.23 & 0.11 & 0.11 & 0.006 & 0.002 \\
\hline C & Bal. & 25.10 & 8.66 & 1.32 & 0.38 & 0.20 & 0.15 & 0.10 & 0.005 & 0.002 \\
\hline D & Bal. & 25.24 & 8.45 & 1.11 & 0.33 & 0.24 & 0.09 & 0.13 & 0.003 & 0.003 \\
\hline
\end{tabular}

Note: Other analyzed elements found to be present in substantially similar trace amounts among the four heats.

plates. These plates were finish annealed at $1175^{\circ} \mathrm{C}\left(2150^{\circ} \mathrm{F}\right)$ for 30 minutes, and then water quenched. While the commercial annealing temperature range for 242 alloy is normally 1065 to $1095^{\circ} \mathrm{C}\left(1950\right.$ to $\left.2000^{\circ} \mathrm{F}\right)$, this higher annealing temperature was selected in order to insure that a consistent, fully recrystallized grain structure was obtained for all heats, and that any and all secondary phase precipitates would be fully dissolved. In fact, grain sizes obtained for all of the laboratory rolled plates were in the range of ASTM $2 \frac{1}{2}-3 \frac{1}{2}$, and as-annealed microstructures were observed to be essentially devoid of significant second phase precipitation upon the grain boundaries.

In order to assess the structure and property effects associated with thermal exposure at temperatures below $1175^{\circ} \mathrm{C}\left(2150^{\circ} \mathrm{F}\right)$, samples of the annealed plates were exposed for both 30 minute and 4 hour durations at intermediate temperatures between $760^{\circ} \mathrm{C}$ and $1040^{\circ} \mathrm{C}\left(1400^{\circ} \mathrm{F}\right.$ and $\left.1900^{\circ} \mathrm{F}\right)$ in $55^{\circ} \mathrm{C}\left(100^{\circ} \mathrm{F}\right)$ increments, and between $1040^{\circ} \mathrm{C}$ and $1150^{\circ} \mathrm{C}\left(1900^{\circ} \mathrm{F}\right.$ and $\left.2100^{\circ} \mathrm{F}\right)$ in $28^{\circ} \mathrm{C}$ $\left(50^{\circ} \mathrm{F}\right)$ increments, followed by a water quench. A sample with no intermediate thermal exposure was included as a control.

Following the various intermediate heat treatments (IHT's), all samples were given a final aging treatment of 72 hours at $650^{\circ} \mathrm{C}$ $\left(1200^{\circ} \mathrm{F}\right)$, and air cooled. The commercial age hardening heat treatment for 242 alloy is normally 24 to 48 hours at this temperaturc. Aging for 72 hours was selected in order to at least partially offset the effects of the coarser than normal grain size, and result in a tensile yield strength level somewhat on the same order as that for commercially produced material.

Most of the initial evaluation of the overall matrix of samples produced was centered upon the materials given a 4 hour IHT, with selective work done for the 30 minute exposed samples. Tensile testing was performed in duplicate at $650^{\circ} \mathrm{C}\left(1200^{\circ} \mathrm{F}\right)$, which is the $Q / C$ test condition for commcrcial material. Samples were oriented in the direction of plate rolling. Corresponding specimens were subjected to detailed examination using light metallography, TEM and SEM. Selected materials were subjected to phase extraction and $\mathrm{x}$-ray analysis.

\section{Tensile Test Results}

\section{Four Hour IHT's}

Results of $650^{\circ} \mathrm{C}\left(1200^{\circ} \mathrm{F}\right)$ tensile tests (average of duplicates) for samples given the 4 hour IHT's are plotted in Figures 1-4. Strength and ductility values shown for the $650^{\circ} \mathrm{C}\left(1200^{\circ} \mathrm{F}\right)$ intermediate heat treatment temperature are actually the results obtained for control samples not given an intermediate heat treatment, but just given the 72 hour final aging treatment at $650^{\circ} \mathrm{C}\left(1200^{\circ} \mathrm{F}\right)$.

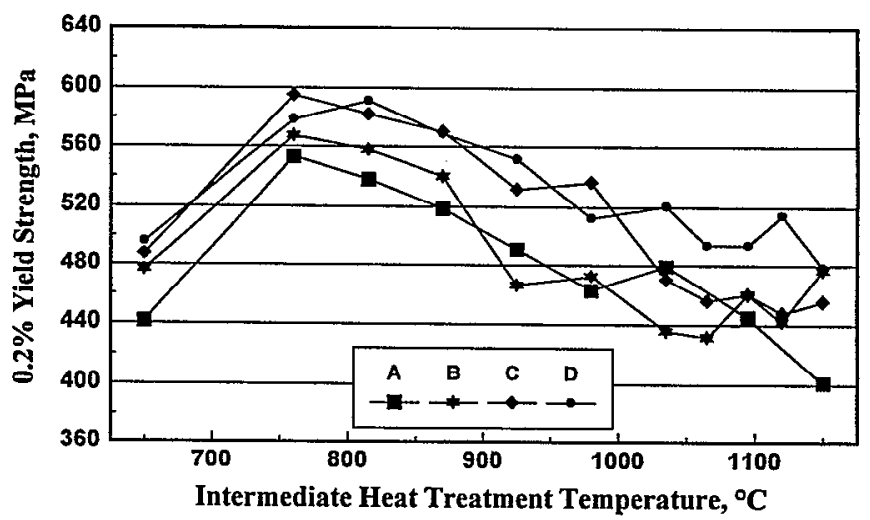

Figure 1: Yield Strength at $650^{\circ} \mathrm{C}\left(1200^{\circ} \mathrm{F}\right)$ for Heats $\mathrm{A}, \mathrm{B}, \mathrm{C}$ and $\mathrm{D}$ as a function of 4-hour IHT temperature.

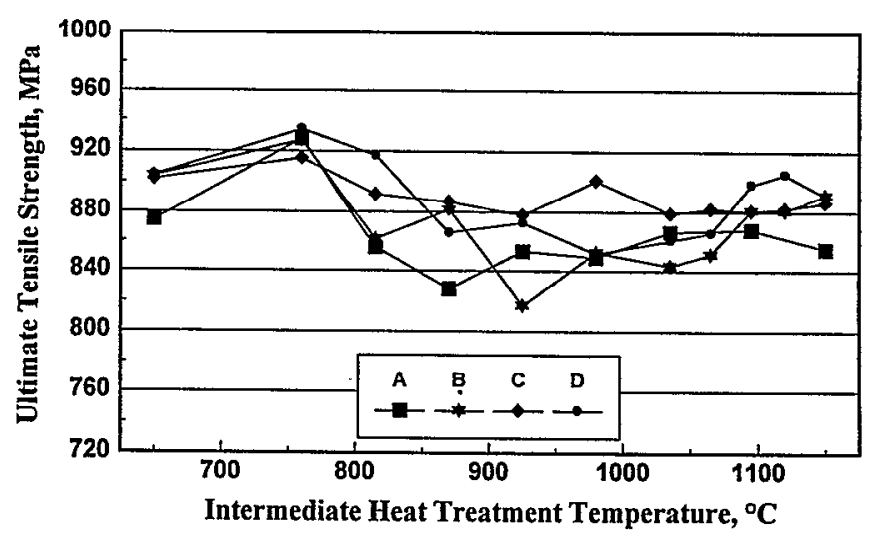

Figure 2: Ultimate Tensile Strength at $650^{\circ} \mathrm{C}\left(1200^{\circ} \mathrm{F}\right)$ for Heats $\mathrm{A}, \mathrm{B}, \mathrm{C}$ and $\mathrm{D}$ as a function of 4-hour IHT temperature.

Yield strength results for the control samples with no IHT ranged from an average of $440 \mathrm{MPa}(64 \mathrm{Ksi})$ for Heat A ("lean") to 495 $\mathrm{MPa}(72 \mathrm{Ksi})$ for Heat D ("rich"), with Heats B and $C$ in between. Ultimate Tensile Strength results exhibited a similar pattern. Tensile ductilities ranged from $48 \%$ elongation and 57\% RA for Heat $A$, to $38 \%$ elongation and $47 \%$ RA for Heat $C$ ("rich"), with Heats $B$ and D in between. Consistency of the duplicate test 
results was very good in all cases. As anticipated, this data for the no-IHT control tests indicates that minor composition variations do exert an influence upon the tensile properties of the alloy.

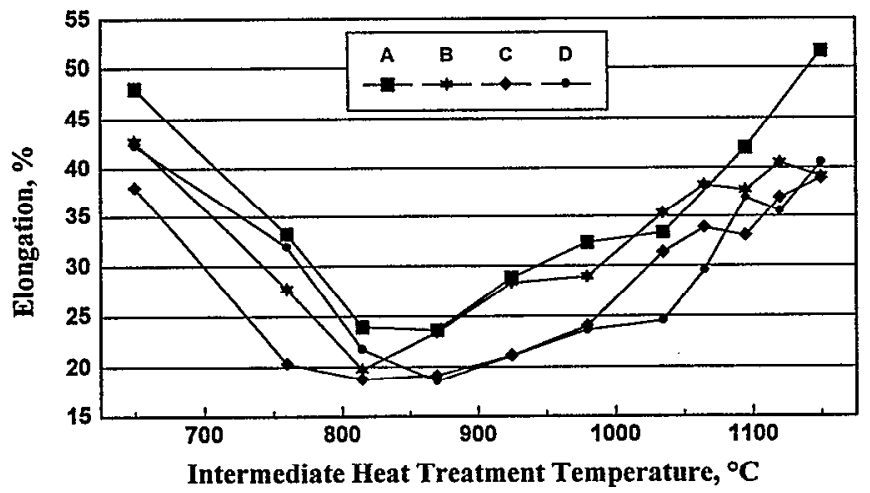

Figure 3: Tensile Elongation at $650^{\circ} \mathrm{C}\left(1200^{\circ} \mathrm{F}\right)$ for Heats A, B, C and $\mathrm{D}$ as a function of 4-hour IHT temperature.

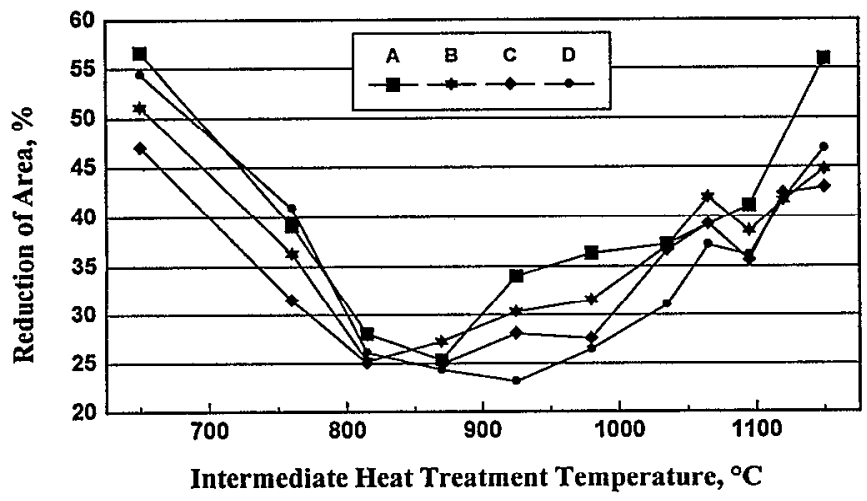

Figure 4: Tensile Reduction of Area at $650^{\circ} \mathrm{C}\left(1200^{\circ} \mathrm{F}\right)$ for Heats $A, B, C$ and $D$ as a function of 4-hour IHT temperature.

As mentioned earlier, it has been reported ${ }^{4}$ that the disordering temperature for the $\mathrm{Ni}_{2}(\mathrm{Mo}, \mathrm{Cr})$ long range ordered domains in 242 alloy is in close proximity to $760^{\circ} \mathrm{C}\left(1400^{\circ} \mathrm{F}\right)$. Kumar and Vasudevan ${ }^{3}$ found that, for exposures up to about 10 hours at $750^{\circ} \mathrm{C}\left(1382^{\circ} \mathrm{F}\right)$, hardening associated with relatively large ordered domain formation was still observed, although longer exposures at this temperature resulted in rapid coarsening of domains, apparent reduction in volume fraction, and loss of hardening. Accordingly, some effects of the four hour IHT at $760^{\circ} \mathrm{C}\left(1400^{\circ} \mathrm{F}\right)$ upon yield strength were anticipated. On the other hand, it was not expected that an IHT at $815^{\circ} \mathrm{C}\left(1500^{\circ} \mathrm{F}\right)$ or above would exhibit any such effects.

Results presented in Figure 1, however, indicate an increase in $650^{\circ} \mathrm{C}\left(1200^{\circ} \mathrm{F}\right)$ yield strength of about $100 \mathrm{MPa}(69 \mathrm{Ksi})$ was obtained with the imposition of IHT's in the range of $760-815^{\circ} \mathrm{C}$ $\left(1400-1500^{\circ} \mathrm{F}\right)$ for four hours. Moreover, as IHT temperatures were increased to above $815^{\circ} \mathrm{C}\left(1500^{\circ} \mathrm{F}\right)$, increased yield strength continued to be observed, albeit to a gradually decreasing extent, until IHT temperatures reached about $980-1035^{\circ} \mathrm{C}\left(1800-1900^{\circ} \mathrm{F}\right)$.
As may be seen in Figure 2, Ultimate Tensile Strength did not exhibit similar behavior. Except for a slight increase observed for four hour IHT at $760^{\circ} \mathrm{C}\left(1400^{\circ} \mathrm{F}\right)$, test results for samples given an IHT were generally the same or lower in value as those for the no-IHT control tests. This behavior may, in part, reflect the tensile ductility effects brought on by the imposition of the IHT's, which are illustrated in Figures 3 and 4.

As may be seen from the plots of both Elongation and RA, signifi -cant loss of tensile ductility resulted from the imposition of IHT's as compared to the no-IHT control samples. The magnitude of this ductility drop was generally worst for IHT at $815-870^{\circ} \mathrm{C}$ $\left(1500-1600^{\circ} \mathrm{F}\right)$, and overall ductlity levels even on the order of the control samples were only observed for IHT's at or above about $1095^{\circ} \mathrm{C}\left(2000^{\circ} \mathrm{F}\right)$. Similar behavior was exhibited among the four study heats, although Heat $A$ results could be judged to be somewhat better than those for the other heats.

\section{Thirty Minute IHT's}

Results of $650^{\circ} \mathrm{C}\left(1200^{\circ} \mathrm{F}\right)$ tensile tests for samples given the 30 minute IHT's are plotted in Figures 5-8. Again, strength and ductility values shown for the $650^{\circ} \mathrm{C}\left(1200^{\circ} \mathrm{F}\right)$ IHT temperature are actually the results obtained for control samples just given the 72 hour final aging treatment at $650^{\circ} \mathrm{C}\left(1200^{\circ} \mathrm{F}\right)$.

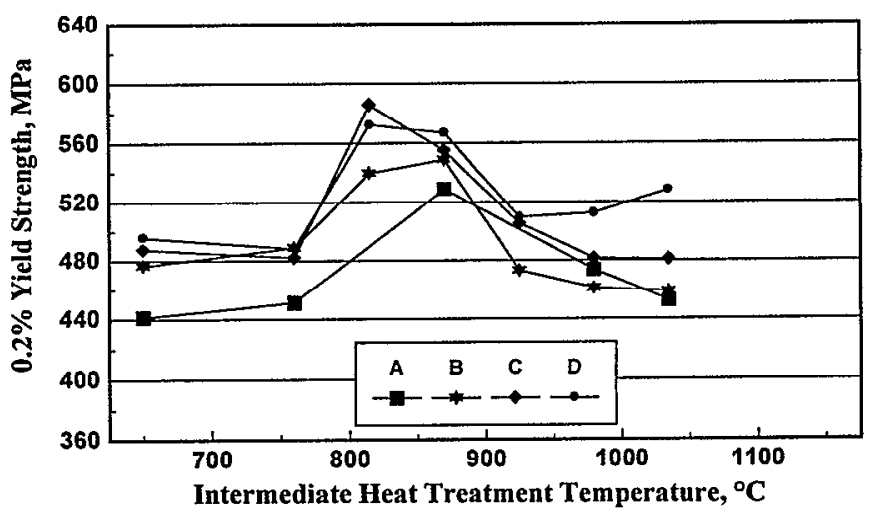

Figure 5: Yield Strength at $650^{\circ} \mathrm{C}\left(1200^{\circ} \mathrm{F}\right)$ for Heats A, B, C and $\mathrm{D}$ as a function of 30-minute IHT temperature.

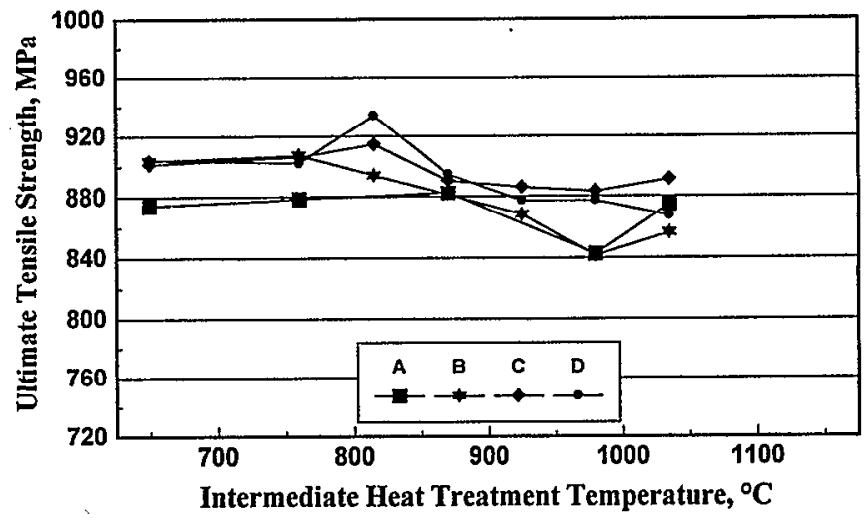

Figure 6: Ultimate Tensile Strength at $650^{\circ} \mathrm{C}\left(1200^{\circ} \mathrm{F}\right)$ for Heats $\mathrm{A}, \mathrm{B}, \mathrm{C}$ and $\mathrm{D}$ as a function of 30 -minute $\mathrm{IHT}$ temperature. 


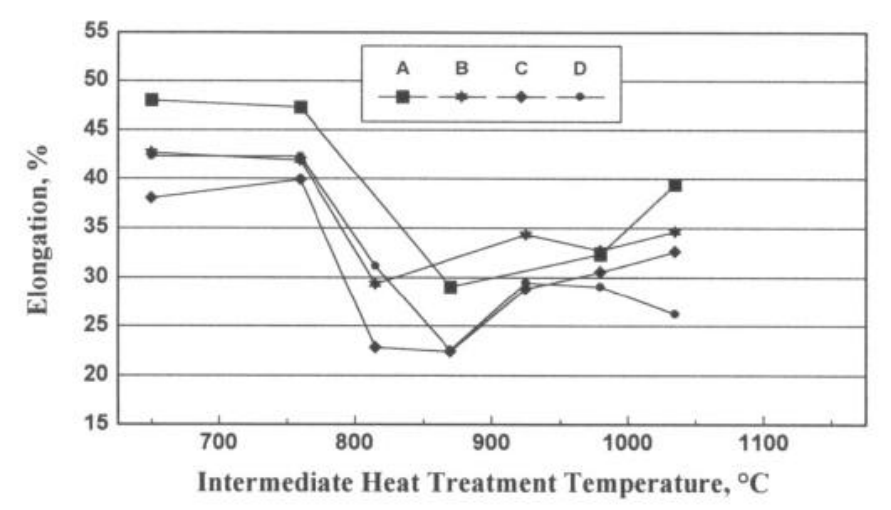

Figure 7: Tensile Elongation at $650^{\circ} \mathrm{C}\left(1200^{\circ} \mathrm{F}\right)$ for Heats A, B, C and $\mathrm{D}$ as a function of 30 -minute IHT temperature.

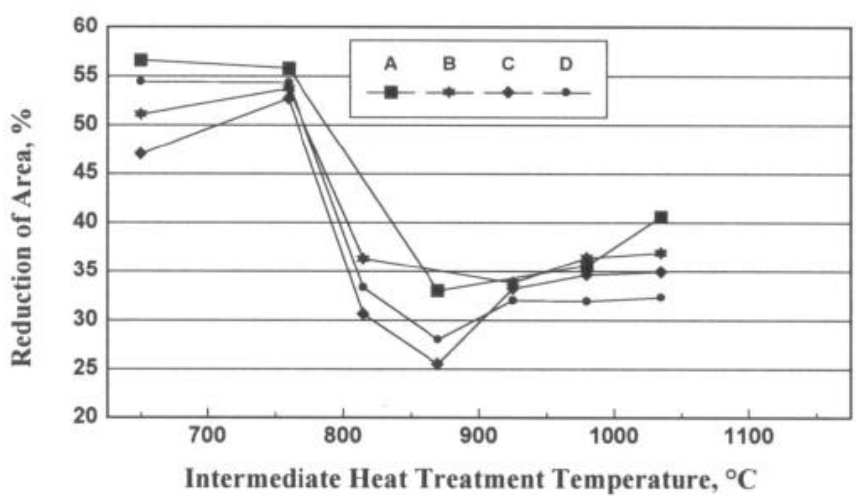

Figure 8: Tensile Reduction of Area at $650^{\circ} \mathrm{C}\left(1200^{\circ} \mathrm{F}\right)$ for Heats $\mathrm{A}, \mathrm{B}, \mathrm{C}$ and D as a function of 30 -minute IHT temperature.

While the highest 30-minute IHT temperature tensile tested was only $1035^{\circ} \mathrm{C}\left(1900^{\circ} \mathrm{F}\right)$, the results, as given in Figures $5-8$, were very similar to those obtained for the 4-hour IHT's, with a few exceptions. First, and most importantly, the $760^{\circ} \mathrm{C}\left(1400^{\circ} \mathrm{F}\right)$ 30-minute IHT, unlike the corresponding 4-hour IHT, produced no significant change in properties compared to the no-IHT control test results. Secondly, the ductility losses exhibited for the 30 -minute IHT's in the $815-870^{\circ} \mathrm{C}\left(1500-1600^{\circ} \mathrm{F}\right)$ range appeared somewhat less severe than those for the 4-hour IHT's. Lastly, the ultimate tensile strength fall off in the $815-870^{\circ} \mathrm{C}\left(1500-1600^{\circ} \mathrm{F}\right)$ range also appeared less pronounced for the shorter IHT.

\section{Metallography, SEM, Extraction \& X-Ray Analysis}

\section{$\underline{\text { Light Metallography }}$}

Light metallography was performed for all four of the heats in all of the finished heat treatment condition iterations utilized in this study. In all cases, structures consisted of fully recrystallized equiaxed grains, in the range of ASTM $2 \frac{1}{2}-3 \frac{1}{2}$ in size, with isolated patches of what appeared to be groups of large, blocky primary carbides spread throughout. In some cases, evidence of decoration of prior grain boundaries with small particles was found. The condition of newly recrystallized grain boundaries was found to vary from essentially clean to heavily and continuously precipitated, apparently dependent upon both the heat treatment imposed and the heat of material in question. A visual summary of the grain boundary conditions observed as a function of heat and heat treatment imposed is presented in Figure 9.

\begin{tabular}{|c|c|c|c|c|}
\hline IHT & Heat $\mathbf{A}$ & Heat B & Heat C & Heat D \\
\hline \multicolumn{5}{|l|}{ None } \\
\hline $760^{\circ} \mathrm{C} / 4$-hours & & & & \\
\hline $815^{\circ} \mathrm{C} / 4$-hours & & & & \\
\hline $870^{\circ} \mathrm{C} / 4$-hours & & & & \\
\hline $925^{\circ} \mathrm{C} / 4$-hours & & & & \\
\hline $980^{\circ} \mathrm{C} / 4$-hours & & & & \\
\hline $1035^{\circ} \mathrm{C} / 4$-hours & & & & \\
\hline $1065^{\circ} \mathrm{C} / 4$-hours & & & & \\
\hline $1095^{\circ} \mathrm{C} / 4$-hours & & & & \\
\hline $1120^{\circ} \mathrm{C} / 4$-hours & & & & \\
\hline $1150^{\circ} \mathrm{C} / 4$-hours & & & & \\
\hline $760^{\circ} \mathrm{C} / 30$-minutes & & & & \\
\hline $815^{\circ} \mathrm{C} / 30$-minutes & & & & \\
\hline $870^{\circ} \mathrm{C} / 30$-minutes & & & & \\
\hline $925^{\circ} \mathrm{C} / 30$-minutes & & & & \\
\hline $980^{\circ} \mathrm{C} / 30$-minutes & & & & \\
\hline $1035^{\circ} \mathrm{C} / 30$-minutes & & & & \\
\hline $1065^{\circ} \mathrm{C} / 30$-minutes & & & & \\
\hline $1095^{\circ} \mathrm{C} / 30$-minutes & & & & \\
\hline $1120^{\circ} \mathrm{C} / 30$-minutes & & & & \\
\hline $1150^{\circ} \mathrm{C} / 30$-minutes & & & & \\
\hline Clean/Light Discrete & & Lt.-Mod. & emi./Cont. & \\
\hline Moderate Discrete & & Mod. & emi./Cont. & \\
\hline Light Semi./Cont. & & & emi./Cont. & \\
\hline
\end{tabular}

Figure 9: Grain boundary precipitate conditions found for Heats $\mathrm{A}, \mathrm{B}, \mathrm{C}$, and D, as a function of IHT, using $500 \mathrm{X}$ microscopy.

The degrees of secondary phase precipitation depicted in Figure 9 reflect qualitative, subjective observations rather than quantitative measurements, and definitive judgements regarding the discrete, semi-continuous, or continuous nature of the grain boundary precipitate morphologies were difficult to make, even at $500 \mathrm{X}$. Nevertheless, an inspection of Figure 9 reveals several key points.

Firstly, significant second phase precipitation at grain boundaries was not observed in any of the four heats for the no-IHT control samples. Secondly, the 30 -minute IHT at $760^{\circ} \mathrm{C}\left(1400^{\circ} \mathrm{F}\right)$ also did not result in significant precipitation at grain boundaries. Thirdly, imposition of IHT's at $760-980^{\circ} \mathrm{C}\left(1400-1800^{\circ} \mathrm{F}\right)$ for four hours, or at $815-980^{\circ} \mathrm{C}\left(1500-1800^{\circ} \mathrm{F}\right)$ for 30 minutes, resulted in significant precipitation of secondary phases at the grain boundaries in samples from all four heats. With the possible exception of Heat A, this precipitation tended to be heaviest for IHT's at $870^{\circ} \mathrm{C}\left(1600^{\circ} \mathrm{F}\right)$, and generally in a semi-continuous to continuous film-like morpohology.

The final key point revealed by Figure 9 is that, for the higher temperature IHT samples, a clear difference in behavior was observed for the four study heats. Heats A and B, the "lean" materials, exhibited grain boundaries that were clean or had light, discrete precipitation in samples given IHT at 1035 or $1065^{\circ} \mathrm{C}$ $\left(1900\right.$ or $\left.1950^{\circ} \mathrm{F}\right)$ or higher. On the otherhand, Heats C and D, 
the "rich" materials, only exhibited such behavior for IHT's at 1095 or $1120^{\circ} \mathrm{C}\left(2000\right.$ or $\left.2050^{\circ} \mathrm{F}\right)$ or higher. This indicates that the secondary precipitation reaction(s) in 242 alloy are indeed influenced by these compositional variations.

\section{$\underline{\text { Scanning Electron Microscopy }}$}

Comprehensive SEM evaluation of no-IHT control samples and samples given 4-hour IHT's was performed. Samples were prepared by electropolishing in a $20 \% \mathrm{H}_{2} \mathrm{SO}_{4}$ - methanol solution, and then electroetching in a $10 \% \mathrm{HCl}$ - methanol solution. Some selective SEM work was done for 30-minute IHT samples from Heats $\mathrm{A}$ and $\mathrm{D}$ as well.

Evaluation of grain boundary structures by SEM yielded results which are in reasonably good qualitative agreement with the observations made for light microscopy. In the main, the no-IHT control samples had clean or light discrete second phase precipitated grain boundaries, although some continuous film-like structure was observed near the isolated large primary carbide clusters.

Samples given 4-hour IHT's at 760 to $870^{\circ} \mathrm{C}\left(1400\right.$ to $\left.1600^{\circ} \mathrm{F}\right)$ tended to exhibit significant amounts of continuous secondary precipitation at the grain boundaries in all heats, apparently consisting of two separate phases. For 4-hour IHT between 925 and $980^{\circ} \mathrm{C}\left(1700\right.$ and $\left.1800^{\circ} \mathrm{F}\right)$, somewhat more semi-continuous precipitate morphology was found, particularly for the "lean" heats A and B. The difference in this behavior is well illustrated by the structures shown for Heats A and D in Figure 10.

For 4-hour IHT's at $1035^{\circ} \mathrm{C}\left(1900^{\circ} \mathrm{F}\right)$ and above, patches of the continuous and semi-continuous precipitate structure were observed less and less frequently, apparently replaced with a significantly lower density of discrete particles of apparently one phase. For 4-hour IHT's at $1095^{\circ} \mathrm{C}\left(2000^{\circ} \mathrm{F}\right)$ and above, only discrete particles were observed.

Behavior consistent with the above was observed for the limited amount of work performed upon the 30-minute IHT samples from Heats A and D, with one exception. For the 30-minute IHT at $760^{\circ} \mathrm{C}\left(1400^{\circ} \mathrm{F}\right)$, no evidence of continuous or semi-continuous second phase precipitation at the grain boundaries was found (again, away from the isolated primary carbide clusters). In general, for all samples examined, IHT at about $815^{\circ} \mathrm{C}\left(1500^{\circ} \mathrm{F}\right)$ produced the heaviest precipitation at the grain boundaries, with that in Heats C \& D somewhat heavier than that in Heats A \& B.

\section{$\underline{\text { Extraction and X-Ray Analysis }}$}

A limited amount of phase extraction work was performed in this study, using a $5 \% \mathrm{H}_{3} \mathrm{PO}_{4}$ plus $10 \% \mathrm{HCl}$ - methanol extraction

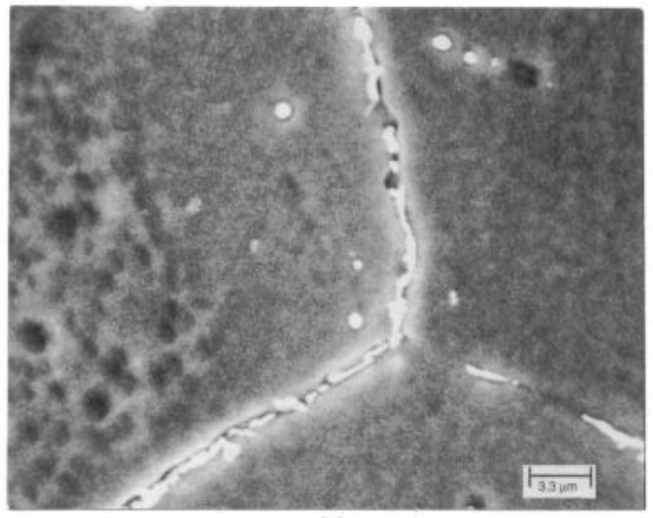

(a)

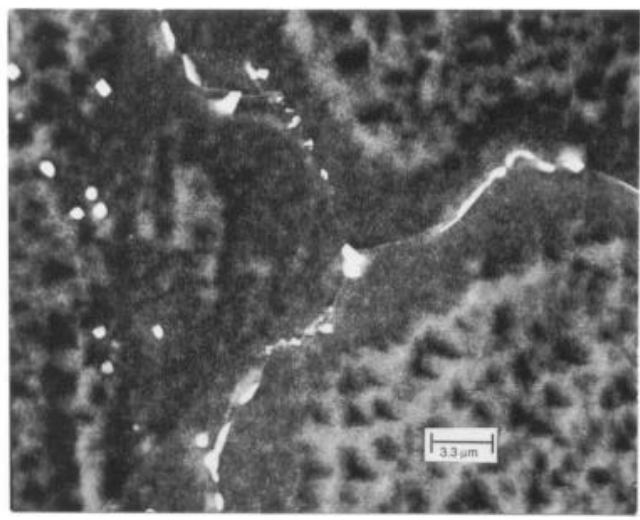

(c)

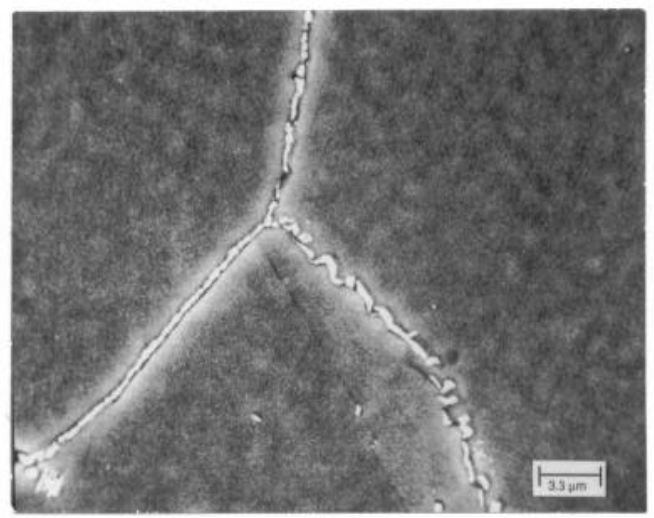

(b)

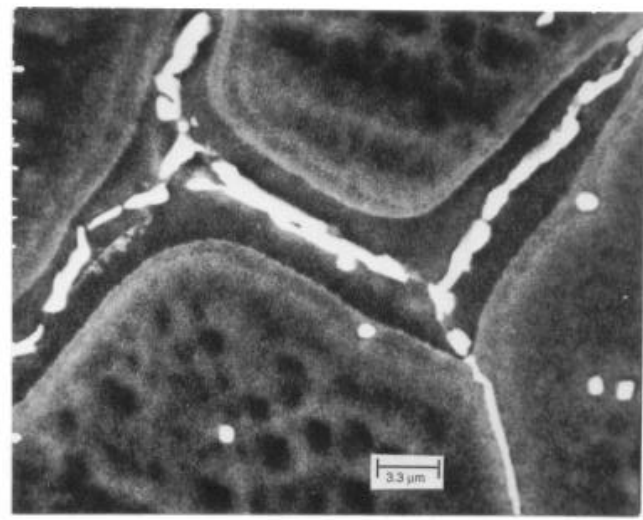

(d)

Figure 10: Scanning electron micrographs for samples of Heats A and D: (a) Heat A, $815^{\circ} \mathrm{C}\left(1500^{\circ} \mathrm{F}\right) / 4-\mathrm{Hour} \mathrm{IHT}$; (b) Heat D, $815^{\circ} \mathrm{C}\left(1500^{\circ} \mathrm{F}\right) / 4$-Hour IHT; (c) Heat A, $980^{\circ} \mathrm{C}\left(1800^{\circ} \mathrm{F}\right) / 4$-Hour IHT; (d) Heat D, $980^{\circ} \mathrm{C}\left(1800^{\circ} \mathrm{F}\right) / 4-\mathrm{Hour} \mathrm{IHT}$. 
media. Film portions of the extracted residues were concentrated by ultrasonically removing the residue every five minutes and decanting the floating films into a separate sample. This residue was used for $\mathrm{x}$-ray diffraction studies, while small portions were used for SEM studies.

Samples used in the extraction were rinsed in alcohol, and re-examined in the SEM. This type of sample provided a 3-D picture of the true morphology of the grain boundary films, and confirmed that the films were being extracted, not preferentially dissolved. An example is shown in Figure 11 for Heat $\mathrm{C}$ given an IHT of $870^{\circ} \mathrm{C}\left(1600^{\circ} \mathrm{F}\right)$ for four hours. EDS analysis of this extracted grain boundary film indicated it to be molybdenum-rich, with lesser amounts of chromium and nickel present.

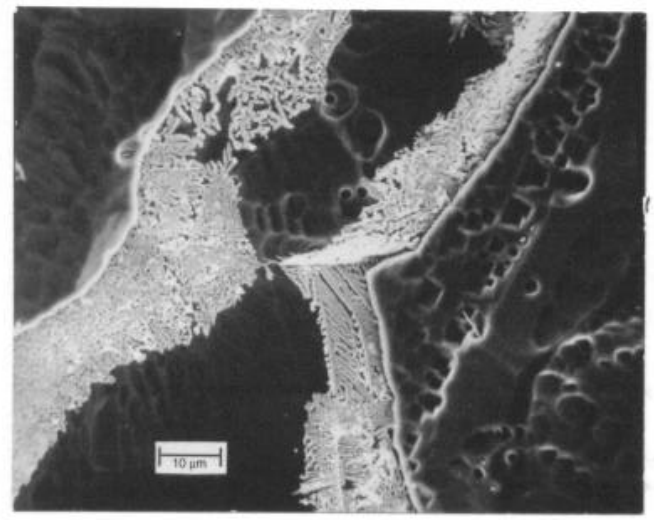

Figure 11: In-situ SEM view of the grain boundary films extracted from a sample of Heat $\mathrm{C}$ given a 4-hour IHT at $870^{\circ} \mathrm{C}\left(1600^{\circ} \mathrm{F}\right)$.

By way of contrast, a view of the extracted residue taken from the no-IHT control sample of Heat C, shown in Figure 12, appears to indicate that the residue was comprised mostly of large and small discrete particles, with little evidence of film structures.

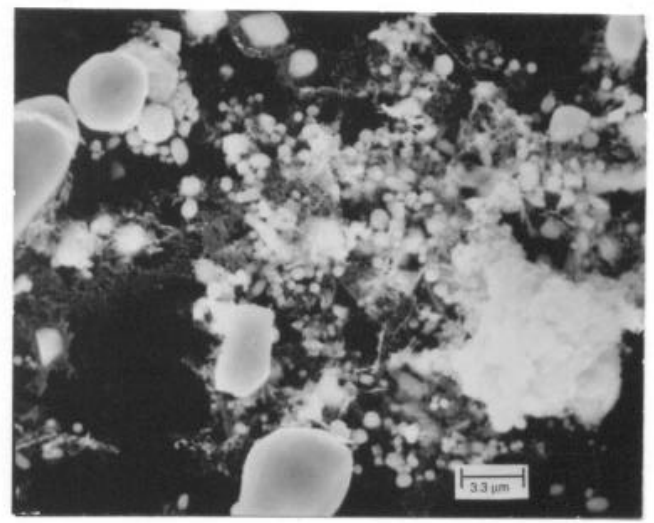

Figure 12: SEM view of the residue extracted from the no-IHT control sample of Heat C.

X-ray diffraction analysis performed upon the residues extracted in this study revealed two patterns, one for $\mathrm{M}_{6} \mathrm{C}$ carbide, and the other best identified as a variant of mu phase. One strong diffraction line for the latter was missing; however, this may have been due to the particular orientation of the films in the residue.

\section{$\underline{\text { Transmission Electron Microscopy }}$}

Transmission electron microscopy was performed upon thin foils prepared from the no-IHT control samples from all four heats, and most of the samples given 4-hour IHT's. Ellipsoidal long range ordered domains on the order of $10-30 \mathrm{~nm}$ in length were observed to be present in all samples. As anticipated from prior work ${ }^{5}$, selected area diffraction patterns for these domains revealed the structure to be similar to an $\mathrm{Ni}_{2} \mathrm{Mo}$ type phase. The size of the domains did not permit EDS analysis using a TEM nano- probe; however, in previously unpublished work by Dollar on 242 alloy exposed for 4000 hours at $650^{\circ} \mathrm{C}\left(1200^{\circ} \mathrm{F}\right)^{6}$, domains up to $200 \mathrm{~nm}$ in length were observed, and EDS analysis using the TEM nanoprobe was performed. Results, given in Table II, confirmed the $\mathrm{Ni}_{2}(\mathrm{Mo}, \mathrm{Cr})$ stoichiometry.

Table II Composition of Ordered Domains in 242 Alloy

\begin{tabular}{ccccc}
\hline & \multicolumn{2}{c}{$\mathrm{Ni}_{2}(\mathrm{Mo}, \mathrm{Cr})$ Domain } & \multicolumn{2}{c}{ Matrix } \\
Element & Weight \% & Atomic \% & Weight \% & Atomic \% \\
\hline $\mathrm{Ni}$ & 56.80 & 64.81 & 65.85 & 71.78 \\
$\mathrm{Mo}$ & 34.58 & 24.15 & 24.31 & 16.22 \\
$\mathrm{Cr}$ & 7.86 & 10.12 & 8.63 & 10.63 \\
$\mathrm{Fe}$ & 0.77 & 0.92 & 1.20 & 1.38 \\
\hline
\end{tabular}

A number of key observations were made from the results of the TEM evaluations. Firstly, despite the use of IHT's prior to final aging at $650^{\circ} \mathrm{C}\left(1200^{\circ} \mathrm{F}\right)$, the $\mathrm{Ni}_{2}(\mathrm{Mo}, \mathrm{Cr})$ ordered domains found in grain interiors in all samples were observed to be of a relatively uniform size within the sample. Secondly, the size of the domains found was significantly increased relative to the no-IHT control samples when 4-hour IHT's at 760 to $815^{\circ} \mathrm{C}\left(1400\right.$ to $\left.1500^{\circ} \mathrm{F}\right)$ were used. This increased domain size was observed to a lesser and lesser degree as IHT temperature increased above $815^{\circ} \mathrm{C}$ $\left(1500^{\circ} \mathrm{F}\right)$, with sizes roughly equivalent to those found for the no-IHT control samples generally observed with IHT at $980^{\circ} \mathrm{C}$ $\left(1800^{\circ} \mathrm{F}\right)$ or above. These observations are illustrated by the TEM dark field images presented in Figures 13 to 15.

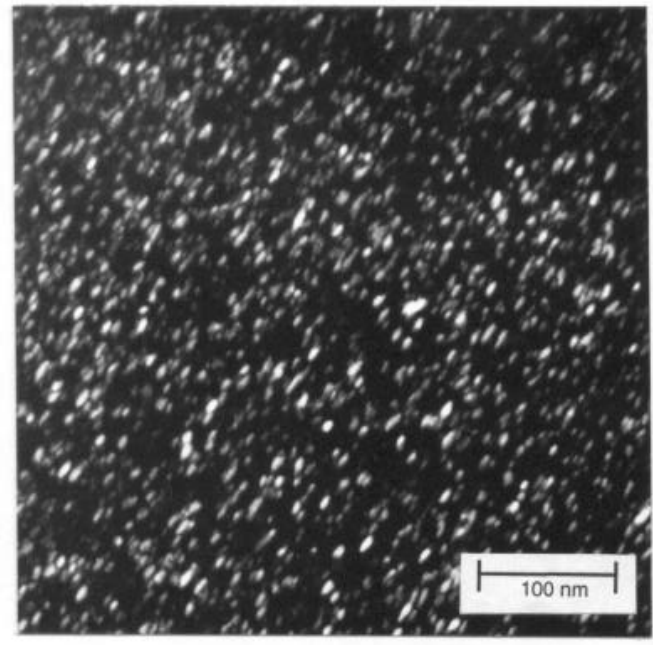

Figure 13: TEM dark field image of ordered domains in the no-IHT control sample from Heat D. 


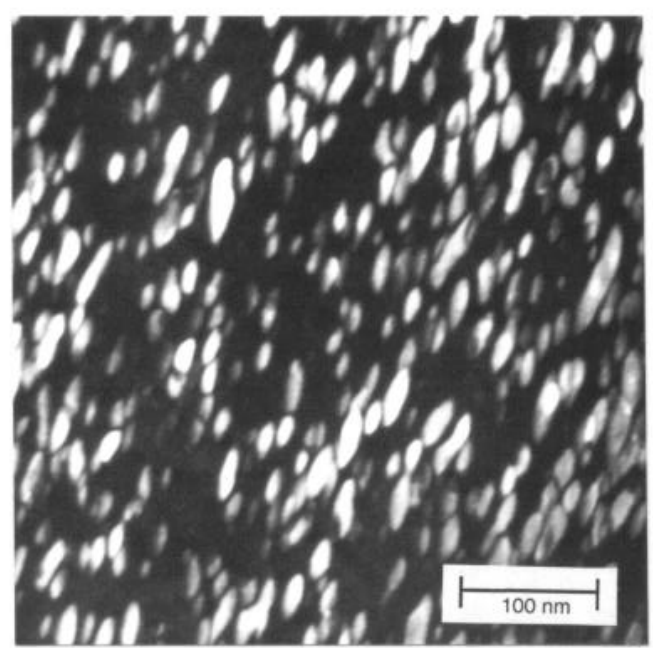

Figure 14: TEM dark field image of ordered domains in the sample from Heat D given a 4-hour IHT at $760^{\circ} \mathrm{C}\left(1400^{\circ} \mathrm{F}\right)$.

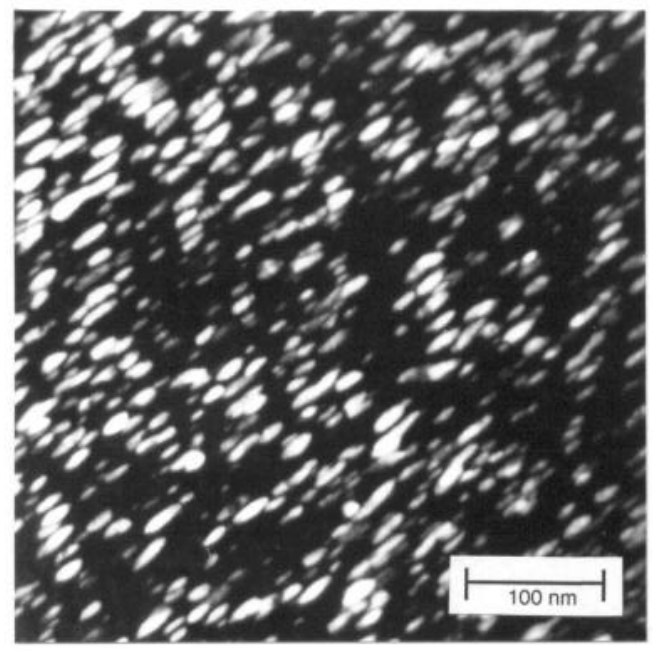

Figure 15: TEM dark field image of ordered domains in the sample from Heat D given a 4-hour IHT at $870^{\circ} \mathrm{C}\left(1600^{\circ} \mathrm{F}\right)$.

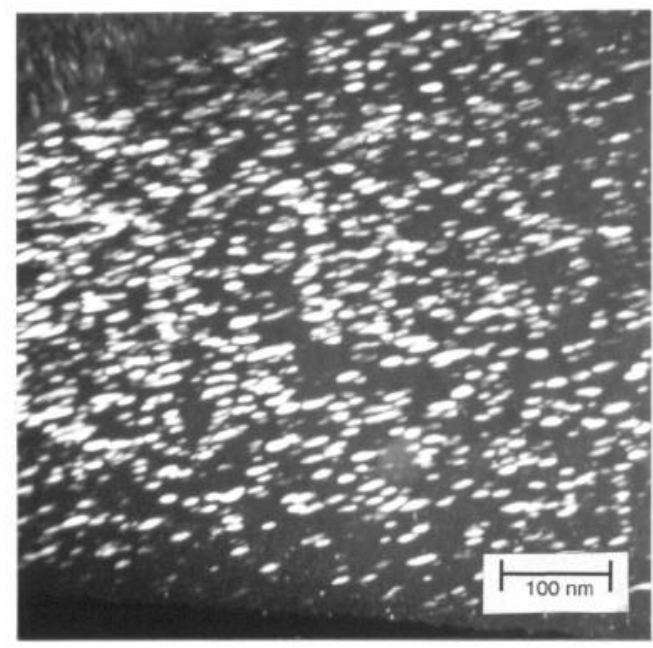

Figure 16: TEM dark field image of ordered domains in the no-IHT control sample from Heat A.
A third important observation made from the TEM evaluations was that the general size of the ordered domains appeared to vary as a function of the heat examined. The domain size observed in the "leaner" materials, Heats A and B, appeared to be larger than that observed in the "richer" materials, Heats C and D, for the same heat treatment condition. This is illustrated by comparing the image shown in Figure 13 for Heat D for the no-IHT control sample, to that in Figure 16 for same condition for Heat $\mathrm{A}$. While the image in Figure 16 is at a lower magnification than that of Figure 13, the domains in the Figure 16 are clearly larger in size.

In addition to the study of the ordered domains, TEM was also used to examine the secondary phase precipitation at the grain boundaries. Confirming the work done with SEM, extraction and $\mathrm{x}$-ray analysis, two grain boundary phases were identified by selected area diffraction techniques - cubic structured $\mathrm{M}_{6} \mathrm{C}$ carbide and hexagonal structured mu phase. The large, isolated primary particles were also confirmed to be $\mathrm{M}_{6} \mathrm{C}$ carbide. The dominant grain boundary phase found in samples given 4-hour IHT's at between 760 and $980^{\circ} \mathrm{C}\left(1400\right.$ and $\left.1800^{\circ} \mathrm{F}\right)$ was found to be the hexagonal mu phase. Above $980^{\circ} \mathrm{C}\left(1800^{\circ} \mathrm{F}\right)$, mu phase was not really found to be in evidence.

\section{Discussion}

\section{$\underline{\text { Structures and Tensile Ductility }}$}

It is not surprising to find that primary and secondary $\mathrm{M}_{6} \mathrm{C}$ carbides were present in the materials studied. Even though the carbon contents of the study heats were only 0.002 to $0.006 \%$, the extremely low solubility of carbon in nickel-molybdenum alloys is well known ${ }^{7}$. The minor loss of tensile ductility that occurs in many nickel-base alloys as a result of precipitation of carbides at grain boundaries during exposure at intermediate temperatures is also well known.

There is a hint of increased ductility loss with IHT at intermediate temperatures for the two highest carbon heats, B and C, associated perhaps with a bit heavier grain boundary precipitation; however, since it was found in the TEM work that the dominant phase precipitating at grain boundaries during IHT between 760 and $980^{\circ} \mathrm{C}\left(1400\right.$ and $\left.1800^{\circ} \mathrm{F}\right)$ is mu phase, the additional relative contribution of the secondary carbide precipitation is hard to assess. Above $980^{\circ} \mathrm{C}\left(1800^{\circ} \mathrm{F}\right)$, it is likely that the $\mathrm{M}_{6} \mathrm{C}$ secondaries are related to the somewhat lower ductility observed.

It is likely, in any case, that the continuous films of predominantly $\mathrm{mu}$ phase formed at the grain boundaries below $980^{\circ} \mathrm{C}\left(1800^{\circ} \mathrm{F}\right)$ are responsible for the majority of the tensile ductility losses shown in Figures 3, 4, 7 and 8. It is also instructive to note that continuous grain boundary films were not observed for the 30 -minute IHT at $760^{\circ} \mathrm{C}\left(1400^{\circ} \mathrm{F}\right)$, but were found for the 4-hour IHT. There was no ductility loss observed for the former, and substantial loss for the latter.

All of the foregoing is not to say that some of the observed loss in ductility isn't simply associated with the higher strength levels achieved with IHT at these temperatures, which is due to a completely separate mechanism. General experience with 242 alloy would indicate that this might account for about $5 \%$ or so lower elongation or RA values in absolute terms. 
Since the formation of continuous grain boundary films was observed in this study for IHT exposures of as little as 30 minutes, it implies that even shorter exposures may be significant. In fact, in unpublished work by $\mathrm{Wu}^{8}{ }^{8}$, it has been found that simply cooling through the intermediate temperature regime at a slow enough rate following annealing can yield results similar to those found here. In his work, the critical cooling time between about 1095 and $650^{\circ} \mathrm{C}\left(2000\right.$ and $\left.1200^{\circ} \mathrm{F}\right)$ was on the order of about two to three minutes or longer.

\section{$\underline{\text { Structures and Strength Properties }}$}

Considering the qualitative observations made with TEM, it would appear that the imposition of an IHT between the solution treatment and $650^{\circ} \mathrm{C}\left(1200^{\circ} \mathrm{F}\right)$ aging steps of the heat treatment for 242 alloy can result in a significant increase in the size of the ordered domains observed following the aging step, depending upon the IHT temperature. This increase in domain size apparently causes the observed increase in yield strength behavior illustrated in Figures 1 and 5. $\Lambda$ mechanistic explanation for this behavior involves particle cutting by dislocations, and is described more fully by Kumar and Vasudevan .

Attempts were made to perform actual domain size measurements for several of the samples in this study in order to better quantify the relationship among IHT, domain size and yield strength. It must be recognized that measurements such as these are highly complicated by factors such as domain orientation to the plane of viewing, amongst others. Nevertheless, the results of these domain measurements were in generally good agreement with the observed yield strength behavior, as illustrated for Heat D data shown in Figure 17.

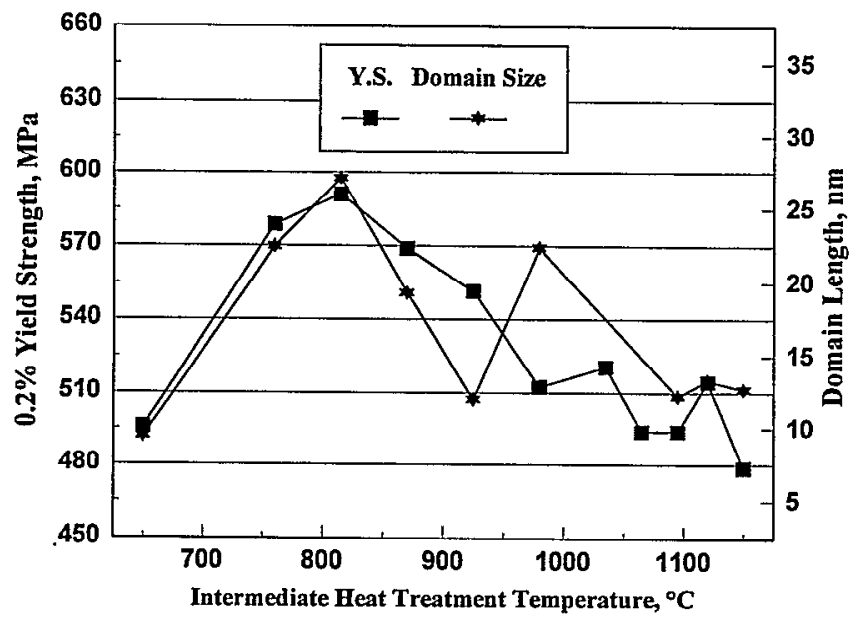

Figure 17: Yield Strength at $650^{\circ} \mathrm{C}\left(1200^{\circ} \mathrm{F}\right)$ \& average measured $\mathrm{Ni}_{2}(\mathrm{Mo}, \mathrm{Cr})$ domain size for Heat $\mathrm{D}$ as a function of 4 -hour IHT temperature.

Kumar and Vasudevan ${ }^{4}$ have cited $766^{\circ} \mathrm{C}\left(1410^{\circ} \mathrm{F}\right)$ as the $\mathrm{Ni}_{2}(\mathrm{Mo}, \mathrm{Cr})$ disordering temperature in 242 alloy, and have observed the continued existence of $\mathrm{Ni}_{2}(\mathrm{Mo}, \mathrm{Cr})$ ordered domains in the alloy after exposure at $750^{\circ} \mathrm{C}\left(1382^{\circ} \mathrm{F}\right)^{3}$. It is therefore conceivable that ordered domains were actually formed during the 4-hour IHT's at $760^{\circ} \mathrm{C}\left(1400^{\circ} \mathrm{F}\right)$ used in this study. If this was indeed the case, the observed absence of a bimodal distribution of domain sizes in the grain interiors indicates that subsequent aging at $650^{\circ} \mathrm{C}\left(1200^{\circ} \mathrm{F}\right)$ served only to grow those domains formed during the IHT at $760^{\circ} \mathrm{C}\left(1400^{\circ} \mathrm{F}\right)$ to a size greater than that achieved with aging at $650^{\circ} \mathrm{C}\left(1200^{\circ} \mathrm{F}\right)$ alone. Again, this size difference may be discerned for Heat $D$, as an example, by comparing Figures 13 and 14.

For IHT at $815^{\circ} \mathrm{C}\left(1500^{\circ} \mathrm{F}\right)$ and above, long range ordered $\mathrm{Ni}_{2}(\mathrm{Mo}, \mathrm{Cr})$ domains should not have been produced, and yet an effect of such IHT's upon both yield strength and domain size following final aging at $650^{\circ} \mathrm{C}\left(1200^{\circ} \mathrm{F}\right)$ is clearly observed. Moreover, the magnitude of the effect appears to gradually diminish as the IHT temperature is increased from $815^{\circ} \mathrm{C}$ $\left(1500^{\circ} \mathrm{F}\right)$ to $980^{\circ} \mathrm{C}\left(1800^{\circ} \mathrm{F}\right)$.

One explanation for this behavior might be that the IHT exposure serves to establish a greater degree of short range order in the alloy relative to that produced by the solution treatment. The magnitude of the increase in short range order could be expected to greatest just above the $\mathrm{Ni}_{2}(\mathrm{Mo}, \mathrm{Cr})$ disordering temperature, and to diminish as IHT temperature increases. A greater degree of short range order thus present in the material prior to aging at $650^{\circ} \mathrm{C}\left(1200^{\circ} \mathrm{F}\right)$ might accelerate the kinetics of formation and $/ \mathrm{or}$ growth of the $\mathrm{Ni}_{2}(\mathrm{Mo}, \mathrm{Cr})$ ordered domains during aging. This would produce the observed increased domain size and attendant increased yield strength.

It should be mentioned that direct measurement of the degree of short range order present in the samples was not attempted in the present study, and may in fact be exceedingly difficult to do. Further work in this area is planned, together with a more definitive examination of structures in the as-intermediate-heattreated condition.

Once again, the fact that IHT effects upon strength were observed for as little as 30-minute exposures implies that even shorter exposures may be significant. In the previously referenced unpublished work by $\mathrm{Wu}^{8}$, cooling rates between the solution annealing temperature and the $650^{\circ} \mathrm{C}\left(1200^{\circ} \mathrm{F}\right)$ aging temperature for 242 alloy were found to have an influence upon yield strength (in addition to that upon tensile ductility) of a similar magnitude to that observed in the present study for isothermal IHT.

\section{Structure, Strength and Chemistry Issues}

One of the key observations made in the TEM portion of this work was that the ordered domain size found in the "leaner" materials, Heats $A$ and $B$, appeared to be larger than that found in the "richer" materials, Heats $C$ and $D$, for the same heat treatment condition. In light of the fact that yield strengths for Heats $C$ and $D$ were observed to be higher than those for Heats A and B for the same heat treatment condition, this appears to be at odds with the conclusion that yield strength increases with increasing domain size.

One possible explanation for this may be that the strengthening effect of the ordered domains is not only a function of the size of the ordered domains, but also a function of thcir volume fraction in the alloy. Such a dual dependency would be consistent with the behavior of most particle-strengthened materials. If the 
volume fraction of $\mathrm{Ni}_{2}(\mathrm{Mo}, \mathrm{Cr})$ ordered domains in 242 alloy increases with molybdenum content, for example, it might be resonably expected that such a larger volume fraction of domains, coupled with a smaller domain size, might net out to a higher level of strength for the "richer" heats C and D than that for the "leaner" heats A and B.

Traditional phase extraction techniques that would permit direct measurement of $\mathrm{Ni}_{2}(\mathrm{Mo}, \mathrm{Cr})$ domain volume fraction in 242 alloy have yet to be developed, and estimates based upon TEM measurements are impractical for a variety of reasons. Thus, it is only possible at this point to demonstrate indirectly that $\mathrm{Ni}_{2}(\mathrm{Mo}, \mathrm{Cr})$ domain volume fraction in 242 alloy increases with increasing molybdenum content. Such indirect evidence is presented in Figures 18 and 19, and in Table III.

The structure shown in Figure 18 is that for Heat $\mathrm{C}$ given a 4-hour IHT at $870^{\circ} \mathrm{C}\left(1600^{\circ} \mathrm{F}\right)$. Note that the grain boundary shown is heavily precipitated with mu and $\mathrm{M}_{6} \mathrm{C}$ carbide phases, which have depleted the adjacent matrix in molybdenum, resulting a zone devoid of $\mathrm{Ni}_{2}(\mathrm{Mo}, \mathrm{Cr})$ domains next to the boundary. With increasing distance away from the grain boundary and towards the the grain interior, molybdenum content is known to increase. The domains encountered nearest to the grain boundary are larger in size and apparently lower in volume fraction than those encountered further into the grain interior, where the molybdenum content is higher. This is consistent with both the domain size behavior observed in the bulk study alloys as a function of heat chemistry, and the postulated volume fraction effect of heat molybdenum content.

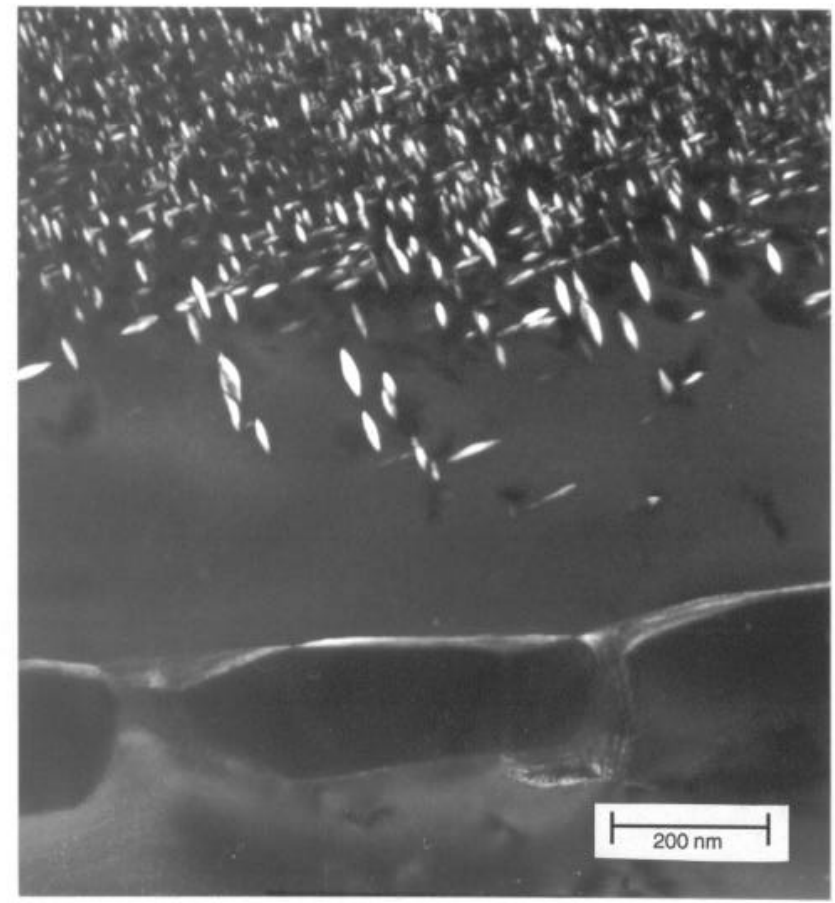

Figure 18: TEM dark field image of grain boundary structure in the sample from Heat $\mathrm{C}$ given a 4-hour IHT at $870^{\circ} \mathrm{C}\left(1600^{\circ} \mathrm{F}\right)$.

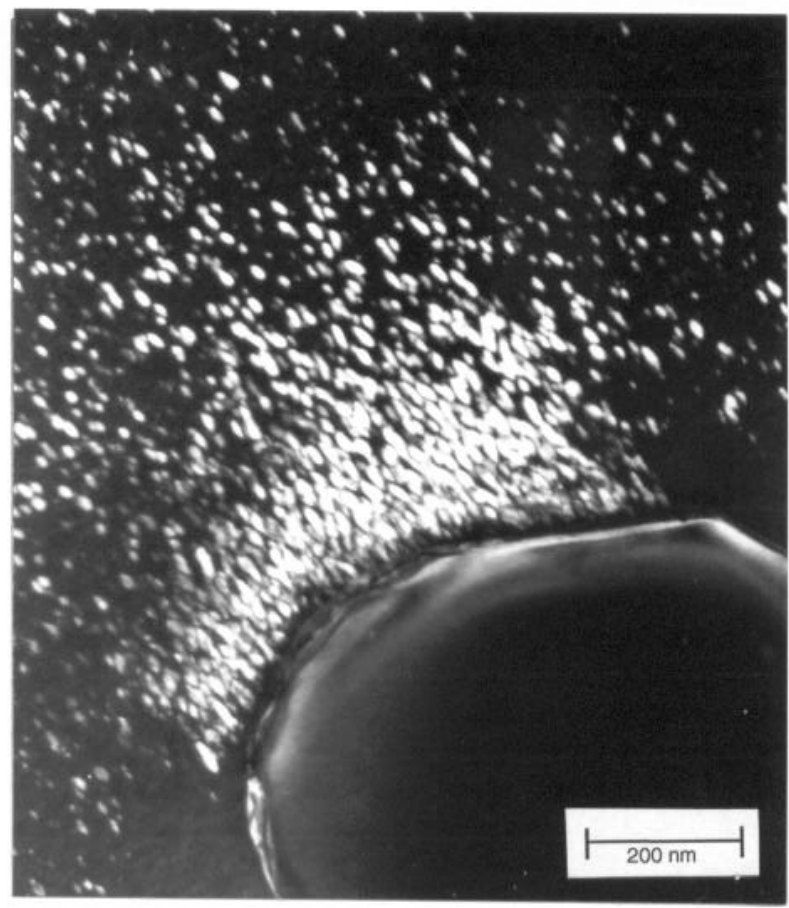

Figure 19: TEM dark field image of structure near a primary $\mathrm{M}_{6} \mathrm{C}$ carbide in the sample from Heat A given a 4-hour IHT at $980^{\circ} \mathrm{C}$ $\left(1800^{\circ} \mathrm{F}\right)$.

The structure shown in Figure 19 is that for Heat $\mathrm{A}$ given a 4-hour IHT at $980^{\circ} \mathrm{C}\left(1800^{\circ} \mathrm{F}\right)$. Note the increase in volume fraction of $\mathrm{Ni}_{2}(\mathrm{Mo}, \mathrm{Cr})$ domains in proximity to the large $\mathrm{M}_{6} \mathrm{C}$ carbide which has apparently undergone some slight dissolution, rejecting molybdenum into the surrounding matrix, as shown in Table III. Again, this supports the postulated effect of heat molybdenum content upon $\mathrm{Ni}_{2}(\mathrm{Mo}, \mathrm{Cr})$ domain volume fraction.

Table III TEM EDS Analyses Relative to Figure 19

\begin{tabular}{ccccc}
\hline & \multicolumn{2}{c}{ Near $\mathrm{M}_{6} \mathrm{C}$ Carbide } & \multicolumn{2}{c}{ Away From Carbide } \\
Element & Weight \% & Atomic \% & Weight \% & Atomic \% \\
\hline $\mathrm{Ni}$ & 61.49 & 68.46 & 63.41 & 69.82 \\
$\mathrm{Mo}$ & 29.05 & 19.79 & 24.31 & 16.22 \\
$\mathrm{Cr}$ & 7.86 & 9.88 & 8.41 & 10.46 \\
$\mathrm{Fe}$ & 1.60 & 1.87 & 1.52 & 1.76 \\
\hline
\end{tabular}

\section{$\underline{\text { Summary and Conclusions }}$}

A comprehensive evaluation of the relationships that exist among the various aspects of metallurgical structure, heat treatment, composition and elevated temperature tensile properties of 242 alloy has been conducted. As a result of this work, a much clearer picture now exists of the factors which control the level of performance properties the material will exhibit in commercial components. 
Major conclusions supported by this work are as follows:

1) 242 alloy achieves its strength from the formation of about 10-30 nm long ellipsoidal, ordered domains with a structure similar to that of $\mathrm{Ni}_{2} \mathrm{Mo}$ phase, and a stoichiometry of $\mathrm{Ni}_{2} \mathrm{X}$, where $\mathrm{X}$ equals about $0.7 \mathrm{Mo}$ atoms and $0.3 \mathrm{Cr}$ atoms.

2) The $650^{\circ} \mathrm{C}\left(1200^{\circ} \mathrm{F}\right)$ yield strength of 242 alloy increases with increasing $\mathrm{Ni}_{2}(\mathrm{Mo}, \mathrm{Cr})$ domain size for a given heat chemistry.

3) $\mathrm{Ni}_{2}(\mathrm{Mo}, \mathrm{Cr})$ domain size in 242 alloy after aging at $650^{\circ} \mathrm{C}$ $\left(1200^{\circ} \mathrm{F}\right)$ will be increased if the final aging is preceded by cxposure for as little as 30 minutes at 815 to $980^{\circ} \mathrm{C}(1500$ to $1800^{\circ} \mathrm{F}$ ), with the size increase diminishing as exposure temperature increases in this range. It is believed that the effect of such exposure is to establish a greater degree of short range order in the material than is present following solution annealing, and thus accelerate the rate of formation and/or growth of the long range ordered domains during final aging.

4) A similar increase in final domain size will be observed if final aging is preceded by a 4 -hour exposure at $760^{\circ} \mathrm{C}\left(1400^{\circ} \mathrm{F}\right)$, but not if a 30-minute exposure is used. This effect may be duc to the actual formation of ordered domains at $760^{\circ} \mathrm{C}\left(1400^{\circ} \mathrm{F}\right)$ in four hours, which are simply grown in size during final aging. The 30-minute exposure may not be long enough to either enhance short range order or form long range ordered domains.

5) It was found that heats with higher molybdenum and chromium contents will exhibit higher yield strengths than those with lower such contents, yet have smaller $\mathrm{Ni}_{2}(\mathrm{Mo}, \mathrm{Cr})$ domain sizes. Indirect evidence indicates that this is a result of increased volume fraction of $\mathrm{Ni}_{2}(\mathrm{Mo}, \mathrm{Cr})$ domains with higher molybdenum content.

6) In addition to the $\mathrm{Ni}_{2}(\mathrm{Mo}, \mathrm{Cr})$ domains, phases to be found in 242 alloy include primary $\mathrm{M}_{6} \mathrm{C}$ carbides, secondary $\mathrm{M}_{6} \mathrm{C}$ carbides, and secondary mu phase. Primary and secondary carbides will be observed even at bulk carbon contents as low as $0.002 \%$.

7) Secondary mu phase and, to a lesser extent, $\mathrm{M}_{6} \mathrm{C}$ carbides will precipitate in 242 alloy, largely in a semi-continuous or continuous grain boundary film morphology, when the alloy is exposed for 30 minutes or longer in the temperature range from 815 to $980^{\circ} \mathrm{C}\left(1500\right.$ to $\left.1800^{\circ} \mathrm{F}\right)$. Similar structures will be observed for 4-hour exposure at $760^{\circ} \mathrm{C}\left(1400^{\circ} \mathrm{F}\right)$, but not for a 30-minute exposure. When present, these grain boundary films will have a strong deleterious effect upon $650^{\circ} \mathrm{C}$ $\left(1200^{\circ} \mathrm{F}\right)$ tensile ductility of fully aged samples.

8) Grain boundaries of the alloy aged directly at $650^{\circ} \mathrm{C}\left(1200^{\circ} \mathrm{F}\right)$ following an effective water quench from the solution treatment temperature will exhibit little or no precipitation which, when found, will normally only be in a discrete particle morphology.

9) $\mathrm{Mu}$ phase will be largely absent for exposure temperatures over $980^{\circ} \mathrm{C}\left(1800^{\circ} \mathrm{F}\right)$. Secondary $\mathrm{M}_{6} \mathrm{C}$ carbides will precipitate as discrete particles at the grain boundaries for exposure temperatures above about $980^{\circ} \mathrm{C}\left(1800^{\circ} \mathrm{F}\right)$, and up to $1150^{\circ} \mathrm{C}$ $\left(2100^{\circ} \mathrm{F}\right)$, with an apparent mild adverse effect upon tensile ductility of fully aged samples.

10) Within the context of this work, the extent of grain boundary precipitation that will occur in 242 alloy does not appear to be strongly dependent upon heat chemistry; however, grain boundary precipitate film morphology will apparently persist to somewhat higher exposure temperatures for heats with higher molybdenum and chromium contents.

\section{Acknowledgements}

The authors would like to acknowledge the considerable assistance of M. Farooqi of IIT, and M. Richeson and J. Cotner of Haynes International, in the performance of this work.

\section{References}

1. M. F. Rothman and H. M. Tawancy, "Low Thermal Expansion Superalloy", U. S. Patent No. 4,818,486, April 4, 1989.

2. H. M. Tawancy, "Long-Term Aging Characteristics of Some Commercial Nickel-Chromium-Molybdenum Alloys", Journal of Materials Science, 16 (1981), 2883-2889.

3. M. Kumar and V. K. Vasudevan, "Ordering Reactions in an Ni-25Mo-8Cr Alloy", Acta Mater., 44 (4) (1996), 1591-1600.

4. M. Kumar and V. K. Vasudevan, "Short-Range to Long-Range Ordering Reactions in a Ni-25Mo-8Cr Alloy", Mater. Res. Soc. Symp. Proc. 213 (1991), 187-192.

5. S. K. Srivastava and B. E. Lewis, "The $\mathrm{Ni}_{2}(\mathrm{Mo}, \mathrm{Cr})$ Ordering Transformation", Kinetics of Ordering Transformations in Metals, ed. H. Chen and V. K. Vasudevan, (Warrendale, PA: TMS, 1992), 141-149.

6. M. Dollar, private communication with the author, Illinois Institute of Technology, 1998.

7. V. L. Gernets, I. A. Tomilin, and T. V. Svistunova, "The Solubility of Carbon in Ni-Mo Alloys", IZV. Akad. Nauk. SSSR, Met (2) (1976), 200-204.

8. R. Wu, private communication with the author, Haynes International, Inc., 1999.

9. M. Kumar and V. K. Vasudevan, "Mechanical Properties and Strengthening of a $\mathrm{Ni}-25 \mathrm{Mo}-8 \mathrm{Cr}$ Alloy Containing $\mathrm{Ni}_{2}(\mathrm{Mo}, \mathrm{Cr})$ Precipitates", Acta Mater., 44 (12) (1996), 4865-4880. 